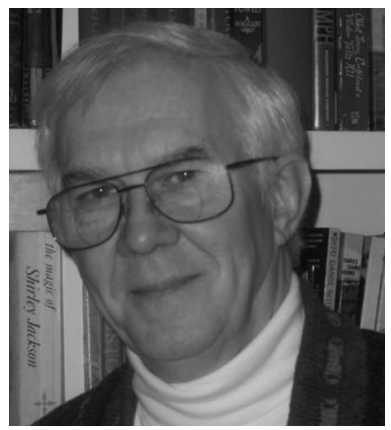

\section{Aware of Pollution}

In retirement, one's memories of early events can dim. There are, however, some that you replay over the years. The basic elements remain fresh in memory although some of the details become hazy. One of my recollections is a reception for new graduate students at the home of Prof. Gerhard Dieke, the chair of the Physics Department at Johns Hopkins in the fall of 1963. In my conversation with Dieke, he talked about his travels in the Southwestern United States. I speculated that the sunsets in that part of the country would be quite beautiful. "No, no," said Dieke. "They are much better here in Baltimore." "Why?" I asked. "Because there is more pollution here." He then proceeded to enlighten me on the basics of atmospheric scattering.

That event first made me aware of pollution. It was not that I hadn't encountered the problem, it's just that I didn't recognize it. After all, I grew up in Akron, Ohio, within sight of the main plant of the Firestone Tire and Rubber Co. and went to grade school and high school up the hill from the main B.F. Goodrich plant. Pollution from the rubber was so much a part of my life, but it didn't register. My wife, who grew up in the Ohio River valley near Wheeling Steel, was just as unaware of the pollution there. There was one type of pollution that had not touched the area, however: light pollution. As a young girl on a farm, the Milky Way was a familiar sight to her. But by the time I visited the farm while courting her, light pollution from Wheeling hid that magnificent sight. It was only on a boat in the Galapagos that we were able to see the Milky Way together.

During my graduate work at Ohio State, I took a summer job with Autonetics in Downey, California, in 1962. When I walked back to my apartment at the end of my first day of work, I was surprised to find tears running down my cheeks. I felt my eyes were smarting. It was my first experience with smog. I pigeonholed "smog" as a Southern California phenomenon. To me, it was not evidence of pollution because, at the time, I was unaware of the concept. It took that comment by Gerhard Dieke to do that.
Then came "That Was the Week That Was" or TW3, as it was called. It was an American version of a satirical news show on the BBC that was broadcast on NBC from January 1964 until May 1965. During its run Tom Lehrer was one of the songwriters on the show. The opening stanza of his "Pollution," written to a Latin American beat, is:

If you visit American city

You will find it very pretty

Just two things of which you must beware

Don't drink the water and don't breathe the air.

For a many Americans in the sixties, this song probably made them aware that their world might be a bit more precarious and not as comfortable as they thought. Between that performance on prime-time television in 1964 and the establishment of Earth Day in 1970, public awareness of the world and our effect on it had changed dramatically.

That year I had started as a rookie professor at Georgia Tech. I bought a neat teaching device, a low-power, pulsed argon-ion laser made by TRW. It was about the size of a briefcase, so that I could do classroom demonstrations with multiple wavelengths instead of the $\mathrm{He}-\mathrm{Ne}$ lasers we used then. Because of its blue-green visibility, we set up a transmission of the beam across campus and return by a World War II surplus retroreflector. This demo led us to do research in detection of $\mathrm{NO}_{2}$, the only atmospheric pollutant with substantial visible absorption. Because there are several strong lines in the argon laser output, it is possible to measure the relative line intensities of retroreflected light and determine the $\mathrm{NO}_{2}$ concentration. My student, Lee Gene Dodge, and I moved the reflector off campus to an office building $3.5 \mathrm{~km}$ (2.2 miles) from the physics building so that the light path crossed a major expressway in Atlanta. We were able to record the variation of $\mathrm{NO}_{2}$ throughout the day. In 1973, however, our detection system consisted of an RCA 1P28 phototube and stripchart recorder for a detection system, so we had to collect a spectral scan for each data point and do the ratios by hand. Still, we were able to observe the buildup of $\mathrm{NO}_{2}$ during the morning, noon, and evening traffic peaks. If you find this interesting, the details of our early 
pollution detection technique can be found in Ref. 1 .

Since then, pollution measurement techniques have been devised, produced, and refined, many of them contributions from optical engineering. Once we were unaware of pollution; now its sources can be identified and quantified to the point where industries now buy and sell credits to pollute. In one realm of pollution there is now a catchy phrase to characterize how badly we treat the world-our "carbon footprint."

We must consider our contributions to this problem. Recycling our trash can help, as does buying higher mileage cars. Yet, these actions can seem to be an exercise in futility when you consider the increasing number of cars in India and China and the major contribution from the incineration of large areas of the rain forests. Still, as with the public health problem of smoking, with a combination of individual effort, public education, and community or governmental regulation, progress on the problems of the pollution of our air and water can be made over many years. At some point you have to move beyond awareness.

\section{References}

1. D. C. O'Shea and L. G. Dodge, "NO 2 concentration measurements in an urban atmosphere using differential absorption techniques," Appl. Opt. 13, 1481-1486 (1974).

Donald C. O'Shea

Editor 